\title{
New aerophytic morphospecies of Cyanobacteria from tropical forest fragments in northwestern São Paulo state, Brazil
}

\author{
Nadia Martins Lemes-da-Silva ${ }^{1,2,3}$, Luis Henrique Zanini Branco ${ }^{1}$ and Orlando Necchi-Júnior ${ }^{1}$
}

Recebido em 9/09/2009. Aceito em 19/08/2010

\begin{abstract}
RESUMO - (Novas morfoespécies aerofíticas de Cyanobacteria de fragmentos de floresta tropical na região noroeste do Estado de São Paulo, Brasil). Algas e cianobactérias podem colonizar uma grande variedade de ambientes terrestres e a composição florística das comunidades desses habitats é praticamente desconhecida. Durante o estudo das algas e cianobactérias aerofíticas de fragmentos florestais na região noroeste do estado de São Paulo, seis populações de cianobactérias não puderam ser identificadas em nível específico e, após estudos morfológicos e métricos, revelaram-se novos morfotipos para a Ciência. Quatro desses pertencem ao gênero Aphanothece (A. excentrica, A. coacervata, A. densa e A. vaginata), um a Phormidium (P. arboricola) e um a Hapalosiphon (H. santannae). Este estudo apresenta a descrição, comparação e proposição das novas morfoespécies e contribui com o conhecimento da diversidade do grupo.
\end{abstract}

Palavras-chave: Cyanobacteria aerofíticas, floresta estacional semideciadual, novas morfoespécies

ABSTRACT - (New aerophytic morphospecies of Cyanobacteria from tropical forest fragments in northwestern São Paulo state, Brazil). Algae and Cyanobacteria can colonize a wide variety of terrestrial environments and the assemblages from aerophytic habitats are very poorly known. During the survey of aerophytic algal and cyanobacterial communities in forest fragments in northwestern São Paulo state, six cyanobacteria populations could not be identified at species level and, after morphological and metrical analysis, proved to be new morphotypes to Science. Four belong to the genus Aphanothece (A. excentrica, A. coacervata, A. densa and A. vaginata), one to Phormidium (P. arboricola) and one to Hapalosiphon (H. santannae). This study presents the description, comparison and proposition of the new morphospecies and improves taxonomic knowledge of the diversity of the group.

Key words: Aerophytic Cyanobacteria, new morphospecies, seasonal semidecidous forest

\section{Introduction}

Algae and cyanobacteria can colonize a wide variety of terrestrial environments, including rocks (Büdel et al. 2002), soil (Evans \& Johansen 1999), walls (Rindi \& Guiry 2004) and tree trunks (Hoffmann 1989). Cyanobacteria are especially common in terrestrial environments and have important ecological functions in the ecosystem, acting to retain silt and clay and adding large amounts of organic carbon and nitrogen to the soil (De 1939; Fletcher \& Martin 1948; Allen 1956; Singh 1961; Whitton 2000), among other properties. However, despite their ecological relevance, taxonomic studies on this group are scarce in the world and most of these focus mainly on edaphic organisms (Johansen 1993; Flechtner et al. 1998; Tirkey \& Adhikary 2006).

Taxonomic knowledge concerning cyanobacteria from terrestrial habitats in Brazil is very limited. Studies regarding the edaphic community from Rio de Janeiro and São Paulo states were presented by Oliveira (1976) and Oliveira et al. (1980). Azevedo (1991), in a study of the edaphic cyanobacterial community of the São Paulo Botanical Garden, found 24 specific taxa distributed in nine families and described a new species of Lyngbyopsis.

Some surveys provide additional information on cyanobacteria from other terrestrial habitats. The study carried out by Sant'Anna (1984) investigated the cyanobacterial flora associated with bryophytes in Campina Grande (Minas Gerais) and recorded 23 species from five different families. Sant'Anna et al. (1991a) described a new species of Gloeothece from "Grutaque-chora" at Sununga beach (Ubatuba, São Paulo). In addition, the aerophytic cyanobacterial flora of the same locality was surveyed by Sant'Anna et al. (1991b) and resulted in the identification of 41 specific taxa from 11 families, including two new species of Calothrix. Büdel et al. (2002) carried out an investigation on the cyanobacteria from inselbergs in the Atlantic forest (eastern Brazil) and found 16 species.

Recent data on aerophytic cyanobacterial flora indicate that knowledge of diversity in the Brazilian territory is still underestimated (e.g., Branco et al. 2009). In addition, new aerophytic morphospecies have been described for different regions of São Paulo state comprising three new Symplocastrum (Branco et al. 2006a), one new Cyanoarbor (Branco et al. 2006b) and three new Nostoc (Sant'Anna et al. 2007), showing how taxonomic accounts are needed.

This work is part of a more comprehensive study on aerophytic algal and cyanobacterial communities from forest fragments in northwestern São Paulo state. During this survey, six new cyanobacterial morphospecies were recorded and are now presented.

\footnotetext{
Universidade Estadual Paulista, Instituto de Biociências, Letras e Ciências Exatas, Departamento de Zoologia e Botânica, São José do Rio Preto, SP, Brazil

Universidade Estadual Paulista, Programa de Pós-Graduação em Biologia Vegetal, Instituto de Biociências, Rio Claro, SP, Brazil

Author for correspondence: nadialemes@gmail.com
} 


\section{Material and methods}

Sampling was carried out between March and May, 2007, in seasonal semideciduous forest fragments occurring in northwestern São Paulo state (Tab. 1).

Detailed description of collection, preservation and study can be found in Lemes-da-Silva et al. (2010). In short, visible growths of algae, cyanobacteria and bryophytes were collected from randomly selected tree bark. The dried material was taken to the laboratory, rehydrated and analyzed under stereoscope microscope and light microscope. For each population found, at least 20 observations of each qualitative or quantitative taxonomic characteristic were made.

The taxa found were described according to the patterns adopted for each group and the following abbreviations were used for species description in text and tables: diam. (diameter) and L/D (cell length/diameter ratio).

The classification system used was that of Hoffmann et al. (2005); holotypes are deposited in the SJRP Herbarium (IBILCE/UNESP - São José do Rio Preto, São Paulo, Brazil).

\section{Results and discussion}

Six new morphospecies of cyanobacteria, belonging to the orders Chroococcales (Aphanothece excentrica, $A$. coacervata, $A$. densa and $A$. vaginata), Oscillatoriales (Phormidium arboricola) and Nostocales (Hapalosiphon santannae) were found.
Aphanothece coacervata N.M. Lemes-da-Silva et al. sp. nov. (Fig. 1A-B)

Diagnosis: Coloniae microscopicae, sphaericae vel cylindricae, cum dense dispositis cellulis; cellulae 3.2-4.8 $\mu \mathrm{m}$ longae, (1.6-)2.4-3.2 $\mu \mathrm{m}$ latae, (1.1-)1.2-1.7(-2.0) longiores quam latiores, contentu olivaceo vel casteneo.

Locus classicus: ad corticem arborum, Municipium Votuporanga, Provincia Sanctus Paulus, Brasilia.

Typus: BRAZIL. São Paulo: Votuporanga, 26/IV/2007, N. M. Lemes-da-Silva (SJRP 28278).

Etymology: The specific epithet refers to cell arrangement, which is densely aggregated in the whole colony.

Colonies microscopic, spherical or cylindrical; cells densely arranged, distributed throughout the whole colony; colonial sheath hyaline, margin well delimited; cells cylindrical, 3.2-4.8 $\mu \mathrm{m}$ long, (1.6-)2.4-3.2 $\mu \mathrm{m}$ diam., L/D (1.1-)1.2 to 1.7(-2.0); cell content homogeneous, light green to brownish.

Occurrence: S3.

Comments: The species most similar to Aphanothece coacervata is $A$. saxicola Nägeli, since they have close

\section{Chroococcales}

Key for identification of the new Aphanothece morphospecies:

1. Cells over $6.0 \mu \mathrm{m}$ diam

3. A. excentrica

1. Cells up to $6.0 \mu \mathrm{m}$ diam.

2. Cells up to $3.2 \mu \mathrm{m}$ diam

1. A. coacervata

2. Cells over $3.2 \mu \mathrm{m}$ diam.

3. Cells densely aggregated in the centre of the colony, blue-green, colonial margin wide, colonial mucilage yellowish brown 2. A. densa

3. Aggregated cells, distributed over the whole colony, usually violet, colonial margin narrow, colonial mucilage hyaline, rarely reddish 4. A. vaginata

cell-length metrics (Tab. 2). However, A. saxicola usually forms macroscopic and amorphous colonies and typical cells are smaller in diameter $(1.0-2.3 \mu \mathrm{m}$ - Komárek \& Anagnostidis 1998).

Aphanothece densa N.M. Lemes-da-Silva et al. sp. nov. (Fig. 1C-D)

Diagnosis: Coloniae microscopicae, sphaericae, cum dense dispositis cellulis in centrum coloniae; coloniae cum vagina luteo-castenea; cellulae 4.0-7.0 $\mu \mathrm{m}$ longae, 4.0-5.0 $\mu \mathrm{m}$ latae, 1.0-1.7 longiores quam latiores, contentu caerulescenti.

Locus classicus: ad corticem arborum, Municipium Sales, Provincia Sanctus Paulus, Brasilia.

Typus: BRAZIL. São Paulo: Votuporanga, 26/IV/2007, N. M. Lemes-da-Silva (SJRP 28276).

Etymology: The specific epithet refers to cells agglomerated in the center of the colony.
Colonies microscopic, spherical; cells densely agglomerated in the center of the colony; colonial sheath yellowish brown, margin well delimited and wide; cells cylindrical, 4.0-7.0 $\mu \mathrm{m}$ long, 4.0-5.0 $\mu \mathrm{m}$ diam., $\mathrm{L} / \mathrm{D} 1.0$ to 1.7; cell content homogeneous, blue-green.

Occurrence: L2, L5, S2, S1.

Comments: Aphanothece pallida (Kützing) Rabenhorst and $A$. variabilis (Schiller) Komárek are the closest taxa to $A$. densa (Tab. 3). Komárek \& Anagnostidis (1998) commented that A. pallida is found in aerophytic environments (soil and wet walls), showing wide geographic distribution; however its cells are longer ((5.67.5-10.5(-16.0) $\mu \mathrm{m})$ and densely arranged at the colony margin (usually with individual sheaths).

According to Komárek \& Anagnostidis (1998), A. variabilis presents densely agglomerated cells, as well as A. densa; however they are distinguishable by the longer cells $(4.2-10.0 \mu \mathrm{m})$ and habitat (marshes and reservoirs) of 
Table 1. Locality and total area of forest remnants where the new morphospecies were found. (L - large area, S - small area).

\begin{tabular}{|c|c|c|c|c|}
\hline Remnant & Municipality & Latitude (S) & Longitude (W) & Area (ha) \\
\hline L1 & Novo Horizonte & $21^{\circ} 31^{\prime} 15^{\prime \prime}$ & $49^{\circ} 17^{\prime} 41^{\prime \prime}$ & 635.0 \\
\hline $\mathrm{L} 2$ & Sales & $21^{\circ} 24^{\prime} 17^{\prime \prime}$ & $49^{\circ} 30^{\prime} 01^{\prime \prime}$ & $1,799.6$ \\
\hline L3 & Planalto & $21^{\circ} 00^{\prime} 05^{\prime \prime}$ & $49^{\circ} 58^{\prime} 26^{\prime \prime}$ & 207.5 \\
\hline L4 & União Paulista & $20^{\circ} 55^{\prime} 16^{\prime \prime}$ & $49^{\circ} 55^{\prime} 34^{\prime \prime}$ & 230.4 \\
\hline L5 & São João da Iracema & $20^{\circ} 28^{\prime} 25^{\prime \prime}$ & $50^{\circ} 17^{\prime} 36^{\prime \prime}$ & $1,656.2$ \\
\hline L9 & Matão & $21^{\circ} 37^{\prime} 14^{\prime \prime}$ & $48^{\circ} 32^{\prime} 14^{\prime \prime}$ & $2,189.6$ \\
\hline $\mathrm{S} 1$ & Vicentópolis & $20^{\circ} 55^{\prime} 34^{\prime \prime}$ & $50^{\circ} 20^{\prime} 55^{\prime \prime}$ & 128.2 \\
\hline $\mathrm{S} 2$ & Ida Iolanda & $20^{\circ} 44^{\prime} 34^{\prime \prime}$ & $49^{\circ} 55^{\prime} 45^{\prime \prime}$ & 66.8 \\
\hline $\mathrm{S} 3$ & Votuporanga & $20^{\circ} 30^{\prime} 52^{\prime \prime}$ & $50^{\circ} 05^{\prime} 12^{\prime \prime}$ & 112.6 \\
\hline $\mathrm{S} 4$ & Turmalina & $20^{\circ} 00^{\prime} 13^{\prime \prime}$ & $50^{\circ} 26^{\prime} 02^{\prime \prime}$ & 108.3 \\
\hline
\end{tabular}

Table 2. Comparison of morphometric and ecological characteristics of Aphanothece saxicola and Aphanothece coacervata (according to Komárek \& Anagnostidis 1998).

\begin{tabular}{|c|c|c|}
\hline & A. saxicola & A. coacervata \\
\hline Colonies & macroscopic, amorphous & microscopic, spherical or cylindrical \\
\hline Sheath & colorless or yellow-brownish & hyaline, margin delimited \\
\hline Cell diam. $(\mu \mathrm{m})$ & $1.0-2.3$ & $(1.6-) 2.4-3.2$ \\
\hline Cell length $(\mu \mathrm{m})$ & $(1.5-) 2.4-4.5(-6.0 ?)$ & $3.2-4.8$ \\
\hline Individual sheath & indistinct, colorless & absent \\
\hline Cells distribution in the colony & more or less densely arranged, throughout the whole colony & densely arranged, throughout the whole colony \\
\hline Ecology & terrestrial - temperate region & terrestrial (epiphyte) - tropical region, Brazil \\
\hline
\end{tabular}

Table 3. Comparison of morphometric and ecological characteristics of Aphanothece pallida, A. variabilis and Aphanothece densa (according to Komárek \& Anagnostidis 1998).

\begin{tabular}{|c|c|c|c|}
\hline & A. pallida & A. variabilis & A. densa \\
\hline Colonies & micro or macroscopic, amorphous & irregular & microscopic, spherical \\
\hline Sheath & $\begin{array}{l}\text { fine, diffluent, greenish, blue-green or } \\
\text { brown when older }\end{array}$ & colorless, margin delimited & $\begin{array}{l}\text { brown yellowish, margin delimited } \\
\text { and wide }\end{array}$ \\
\hline Cell diam. $(\mu \mathrm{m})$ & $(3.2-) 5.0-8.0$ & $2.5-7.0$ & $4.0-5.0$ \\
\hline Cell length $(\mu \mathrm{m})$ & $\begin{array}{l}(5.6-) 7.5-10.5 \\
(-16.0)\end{array}$ & $4.2-10.0$ & $4.0-7.0$ \\
\hline Cells distribution in the colony & $\begin{array}{l}\text { loosely (in the colonial center) to densely } \\
\text { arranged }\end{array}$ & $\begin{array}{l}\text { densely arranged, in the center } \\
\text { of the colony }\end{array}$ & $\begin{array}{l}\text { densely arranged, in the center of the } \\
\text { colony }\end{array}$ \\
\hline Ecology & terrestrial - cosmpolitan & swamps - pantropical & $\begin{array}{c}\text { terrestrial (epiphyte) - tropical region, } \\
\text { Brazil }\end{array}$ \\
\hline
\end{tabular}

the former species. Cell arrangement in A. densa is similar to genus Asterocapasa, but individual sheath with wart-like process is a diagnostic characteristic in Asterocapsa and they are absent in $A$. densa.

Aphanothece excentrica N.M. Lemes-da-Silva et al. sp. nov. (Fig. 1E-F)

Diagnosis: Coloniae microscopicae, sphaericae, cum dense dispositis celullis; cellulae 7.2-8.8(-10.8) $\mu \mathrm{m}$ longae, (5.6-)6.4-7.2(-8.0) $\mu \mathrm{m}$ latae, (1.1-)1.2-1.4(-1.5) longiores quam latiores, contentu granuloso, olivaceo vel griseo; cellulae cum vagina granulata, ferruginea et asymetrica.

Locus classicus: ad corticem arborum, Municipium Votuporanga, Provincia Sanctus Paulus, Brasilia.

Typus: BRAZIL. São Paulo: Votuporanga, 26/IV/2007, N. M. Lemes-da-Silva (SJRP 28279).

Etymology: The specific epithet refers to individual sheath in some cells which is asymmetrical, out of cell center, i.e., eccentric.

Colonies microscopic, spherical; cells densely arranged, distributed throughout the whole colony; colonial sheath hyaline, margin well delimited; cells cylindrical, 7.2-8.8(- 

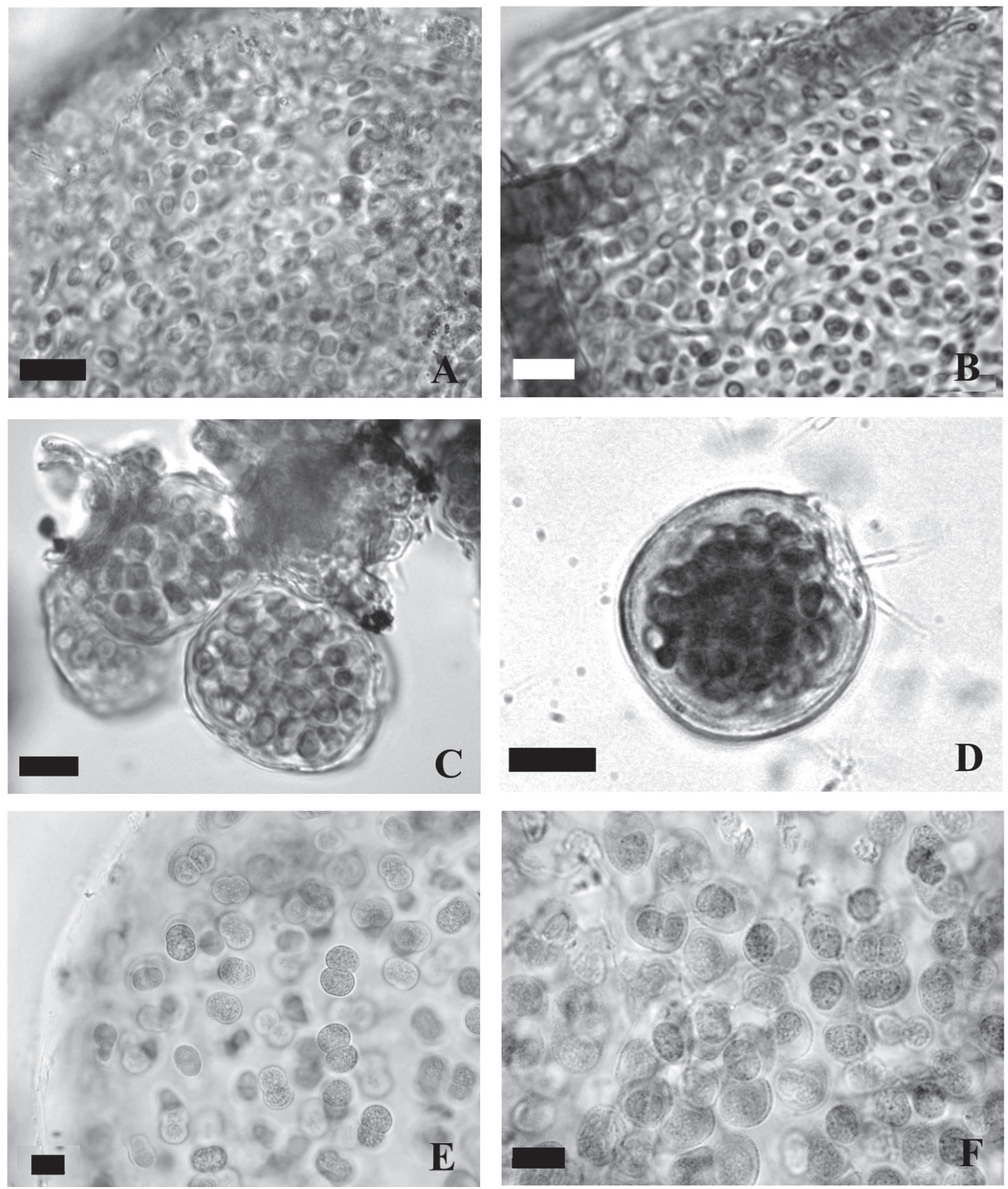

Figure 1. A-B. Aphanothece coacervata. C-D. A. densa. E-F. A. excentrica. Scale bars $=10 \mu \mathrm{m}$.

10.8) $\mu \mathrm{m}$ long, (5.6-)6.4-7.2(-8.0) $\mu \mathrm{m}$ diam., L/D (1.1-)1.2 to 1.4(-1.5); cell content granular, green or grayish green; some cells with individual, reddish, asymmetrical, granular sheath.

Occurrence: S3.

Comments: This population presents metrics similar to Aphanothece pallida (Kützing) Rabenhorst (Tab. 4), however the cells are distributed along the colony margin and each one is surrounded by an individual concentrically lamellate sheath in the latter, while in $A$. excentrica the individual sheath is asymmetrical and granular, when present. An additional morphological incompatibility between the two taxa is the presence of greenish to brownish sheath in A. pallida and colorless in $A$. excentrica. The two species are also ecologically distinguishable since $A$. pallida is typically a soil-andwet-walls inhabitant and $A$. excentrica was found on tree 
Table 4. Comparison of morphometric and ecological characteristics of Aphanothece pallida and Aphanothece excentrica (according to Komárek \& Anagnostidis 1998).

\begin{tabular}{|c|c|c|}
\hline & A. pallida & A. excentrica \\
\hline Colonies & micro or macroscopic, amorphous & microscopic, spherical \\
\hline Sheath & thin, diffluent, greenish, blue-green or brown when older & hyaline, margin delimited \\
\hline Cell diam. $(\mu \mathrm{m})$ & $(3.2-) 5.0-8.0$ & $(5.6-) 6.4-7.2(-8.0)$ \\
\hline Cell long $(\mu \mathrm{m})$ & $(5.6-) 7.5-10.5(-16.0)$ & $7.2-8.8(-10.8)$ \\
\hline Individual sheath & concentrically lamellate, yellow-brown & asymmetrical, granular, reddish \\
\hline Cells distribution in the colony & loosely (in the colonial center) to densely arranged & densely arranged, throughout the whole colony \\
\hline Ecology & terrestrial edaphic - cosmopolitan & terrestrial (epiphyte) - tropical region, Brazil \\
\hline
\end{tabular}

trunks. This morphospecies of Aphanothece shares some characteristics with the genus Asterocapsa, mainly the colored granular individual sheaths in some cells, but Asterocapsa shows solitary cells or grouped with few cells and the colony sheath presents wart-like projections of different lengths.

Aphanothece vaginata N.M. Lemes-da-Silva et al. sp. nov. (Fig. 2A-B)

Diagnosis: Coloniae microscopicae, sphaericae vel cylindricae, cum dense dispositis cellulis; coloniae cum vagina hyalina usque ferruginea; cellulae (4.8-)5.6-7.2(-8.0) $\mu \mathrm{m}$ longae, (3.2-)4.0-4.8(-6.0) $\mu \mathrm{m}$ latae, 1.2-1.6 longiores quam latiores, contentu olivaceo usque violeo.

Locus classicus: ad corticem arborum, Municipium Votuporanga, Provincia Sanctus Paulus, Brasilia.

Typus: BRAZIL. São Paulo: Votuporanga, 26/IV/2007, N. M. Lemes-da-Silva (SJRP 28280).

Etymology: The specific epithet refers to colonial sheath with well-delimited margin.

Colonies microscopic, spherical to cylindrical, cells densely arranged, distributed throughout the whole colony; colonial sheath hyaline, rarely reddish, margin welldelimited; cells cylindrical, (4.8-)5.6-7.2(-8.0) $\mu \mathrm{m}$ long, (3.2-)4.0-4.8(-6.0) $\mu \mathrm{m}$ diam., L/D 1.2 to 1.6; cell content homogeneous, green to violet.

Occurrence: S3.

Comments: Aphanothece vaginata is close to $A$. castagnei (Brébisson) Rabenhorst (Tab. 5). According to Komárek \& Anagnostidis (1998), colonies of A. castagnei are macroscopic and irregularly spherical to amorphous and the cells, with individual lamellate and yellowish brown envelopes, are distributed along the colony margin, differing from $A$. vaginata.

Some species of Aphanothece described in this study were found in the same forest fragment but they are clearly separated and recognizable on the basis of their morphology and metrics (Tab. 6).

Phormidium arboricola N.M. Lemes-da-Silva et al. sp. nov. (Fig. 2C-D)
Diagnosis: Fila flexuosa, (8.0-)10.0-12.0 $\mu \mathrm{m}$ latae; vaginae hyalinae usque casteneae; trichomatibus abusque constrictis, (7.0-)9.0-10.0 $\mu \mathrm{m}$ latae; articulis (6.0-)8.0-10.0 $\mu \mathrm{m}$ longis, 0.6-1.0(-1.42) longiores quam latiores; cellula apicalis rotundata conica.

Locus classicus: ad corticem arborum, Municipium São João da Iracema, Provincia Sanctus Paulus, Brasilia.

Typus: BRAZIL. São Paulo: São João da Iracema, 25/ IV/2007, N. M. Lemes-da-Silva (SJRP 28277).

Etymology: The specific epithet refers to typical habitat (on tree bark) where organisms of this species are found.

Filaments isolated or forming small aggregates of entangled filaments; filaments slightly waved, (8.0-)10.0$12.0 \mu \mathrm{m}$ diam.; sheath thin, hyaline to brown, homogeneous; trichomes not constricted, (7.0-) 9.0-10.0 $\mu \mathrm{m}$ diam.; cells cylindrical, (6.0-)8.0-10.0 $\mu \mathrm{m}$ long, L/D 0.6 to 1.0(-1.42); apical cell conical-rounded; cell content homogeneous, grayish green.

Occurrence: L1, L2, L4, L5, L9, S2, S3, S4.

Comments: Phormidium corbieri (Frémy) Anagnostidis \& Komárek and $P$. ornatum (Kützing ex Gomont) Anagnostdis \& Komárek are the species most similar to the Brazilian populations (Tab. 7). They have cell diameter similar to that of Phormidium arboricola, however both species are found in periphyton of European environments, significantly differing from the studied populations.

Phormidium usteri Schmidle has been recorded for Brazilian soils (Komárek \& Anaginostidis 2005), but trichome diameter is narrower $(3.0-4.0 \mu \mathrm{m})$. The aerophytic Phormidium rubroterricola Gardner and P. jadinianum Gomont present smaller cell diameter, while $P$. durum Gardner is distinguishable from $P$. arboricola by having greater trichome diameter.

Hapalosiphon santannae N.M. Lemes-da-Silva et al. sp. nov. (Fig. 2E-F)

Diagnosis: Fila agglutinata, fasciculi erecti; fila primaria et secundaria dimensionibus similaria, 16.0-20.0 
Table 5. Comparison of morphometric and ecological characteristics of Aphanothece castagnei and Aphanothece vaginata (according to Komárek \& Anagnostidis 1998).

\begin{tabular}{lcc}
\hline & $A$. castagnei & A. vaginata \\
\hline Colonies & macroscopic, spherical to amorphous & microscopic, spherical or cylindrical \\
Sheath & brown & $(2.0-) 3.0-4.8(-5.5)$ \\
Cell diam. $(\mu \mathrm{m})$ & $(3.8-) 4.0-8.0$ & $(3.2-) 4.0-4.8(-6.0)$ \\
Cell length $(\mu \mathrm{m})$ & lamellate, yellowish brown \\
Individual sheath & more or less densely arranged, throughout the whole colony & densely arranged, throughout the whole colony \\
Cells distribution in the colony & terrestrial - temperate region & terrestrial (epiphyte) - tropical region, Brazil \\
Ecology &
\end{tabular}

Table 6. Comparison of morphometric characteristics of the Aphanothece found species.

\begin{tabular}{|c|c|c|c|c|}
\hline & A. coacervata & A. densa & A. excentrica & A. vaginata \\
\hline Colonies & spherical or cylindrical & spherical & spherical & Spherical or cylindrical \\
\hline Sheath & hyaline, margin delimited & $\begin{array}{l}\text { brown yellowish, margin } \\
\text { delimited and wide }\end{array}$ & hyaline, margin delimited & hyaline to reddish, margin delimited \\
\hline Cell color & green to brown & blue-green & green to greyish & green to violet \\
\hline Cell diam. $(\mu \mathrm{m})$ & $(1.6-) 2.4-3.2$ & $4.0-5.0$ & $(5.6-) 6.4-7.2(-8.0)$ & $(3.2-) 4.0-4.8(-6.0)$ \\
\hline Cell length $(\mu \mathrm{m})$ & $3.2-4.8$ & $4.0-7.0$ & $7.2-8.8(-10.8)$ & $(4.8-) 5.6-7.2(-8.0)$ \\
\hline $\mathrm{L} / \mathrm{D}$ & $(1.1-) 1.25$ to $1.67(-2.0)$ & 1.0 to 1.75 & $(1.1-) 1.25$ to $1.37(-1.5)$ & 1.2 to 1.6 \\
\hline Individual sheath & absent & absent & $\begin{array}{l}\text { asymmetrical, granular, } \\
\text { reddish }\end{array}$ & absent \\
\hline $\begin{array}{l}\text { Cells distribution in } \\
\text { the colony }\end{array}$ & $\begin{array}{l}\text { densely arranged, throughout } \\
\text { the whole colony }\end{array}$ & $\begin{array}{l}\text { densely arranged, in the } \\
\text { center of the colony }\end{array}$ & $\begin{array}{l}\text { densely arranged, throughout } \\
\text { the whole colony }\end{array}$ & $\begin{array}{l}\text { densely arranged, throughout the } \\
\text { whole colony }\end{array}$ \\
\hline
\end{tabular}

Table 7. Morphometric and ecological characteristics of Phormidium arboricola and the closest species (according to Komárek \& Anagnostidis 2005).

\begin{tabular}{|c|c|c|c|c|c|c|c|}
\hline & P.corbieri & P. durum & P. jadinianum & P.ornatum & P.rubroterricola & P. usteri & P. arboricola \\
\hline Filament diam. $(\mu \mathrm{m})$ & & & & & & & $8.0-12.0$ \\
\hline Trichome diam. $(\mu \mathrm{m}$ & $9.0-10.0$ & $12.0-14.0$ & $4.0-6.0$ & $\begin{array}{c}(6.0-) 9.0- \\
11.5(-15.0)\end{array}$ & $2.2-2.4$ & $3.0-4.0$ & $7.0-10.0$ \\
\hline $\begin{array}{l}\text { Cell } \\
\text { length }(\mu \mathrm{m})\end{array}$ & $3.5-4.0$ & & $2.0-3.5$ & $2.0-5.5$ & & & $6.0-10.0$ \\
\hline $\mathrm{L} / \mathrm{D}$ & $\begin{array}{l}\text { shorter } \\
\text { than wide }\end{array}$ & $\begin{array}{l}\text { isodiametric or } \\
2 \text { times longer } \\
\text { than wide }\end{array}$ & & $\begin{array}{c}0.2-0.5 \text { times } \\
\text { longer than } \\
\text { wide }\end{array}$ & isodiametric & $\begin{array}{l}\text { shorter than } \\
\text { wide }\end{array}$ & $0.6-1.0$ \\
\hline Apical cell & rounded & rounded & $\begin{array}{l}\text { elongated or } \\
\text { acute-conical }\end{array}$ & hemispherical & bluntly conical & rounded & conical- rounded \\
\hline Constriction & $\begin{array}{c}\text { not } \\
\text { constricted }\end{array}$ & not constricted & constricted & constricted & not constricted & not constricted & not constricted \\
\hline Ecology & $\begin{array}{l}\text { freshwater } \\
\text { - France }\end{array}$ & $\begin{array}{l}\text { aerophytic - } \\
\text { Puerto Rico }\end{array}$ & $\begin{array}{l}\text { trunks, soils } \\
\text { and streams - } \\
\text { tropical region }\end{array}$ & $\begin{array}{c}\text { freshwater, } \\
\text { benthic - } \\
\text { cosmopolitan }\end{array}$ & $\begin{array}{l}\text { aerophytic - } \\
\text { India, Puerto } \\
\text { Rico, tropical } \\
\text { region Brazil }\end{array}$ & $\begin{array}{l}\text { aerophytic, } \\
\text { soil - India, } \\
\text { Philippines, } \\
\text { tropical region } \\
\text { Brazil }\end{array}$ & $\begin{array}{l}\text { aerophytic - trunks, } \\
\text { tropical region, Brazil }\end{array}$ \\
\hline
\end{tabular}

intercalary or lateral, (8.0-)10.0-12.0 $\mu \mathrm{m}$ long, (12.0-)14.0$16.0 \mu \mathrm{m}$ diam.

Occurrence: L3.

Comments: Hapalosiphon fontinalis (Agardh) Bornet has filament diameter comparable to Hapalosiphon santannae, however it is found in aquatic environments and has longer than wide cells (Tab. 8).

In the most extensive survey of true-branched Nostocales carried out in São Paulo state, Silva \&
Sant'Anna (1990) found six species of Hapalosiphon, all occurring in aquatic environments, except for $H$. stuhlmannii Hieronimus that was also found growing on wet rocky wall and soil, but with different filament diameter ((4.0-)5.9-11.5(-14.3) $\mu \mathrm{m})$ than Hapalosiphon santannae. Azevedo et al. (1996) recorded H. stuhlmannii in edaphic environment in São Paulo state; however the morphological and metric characteristics differ from those of Hapalosiphon santannae (Tab. 8). 

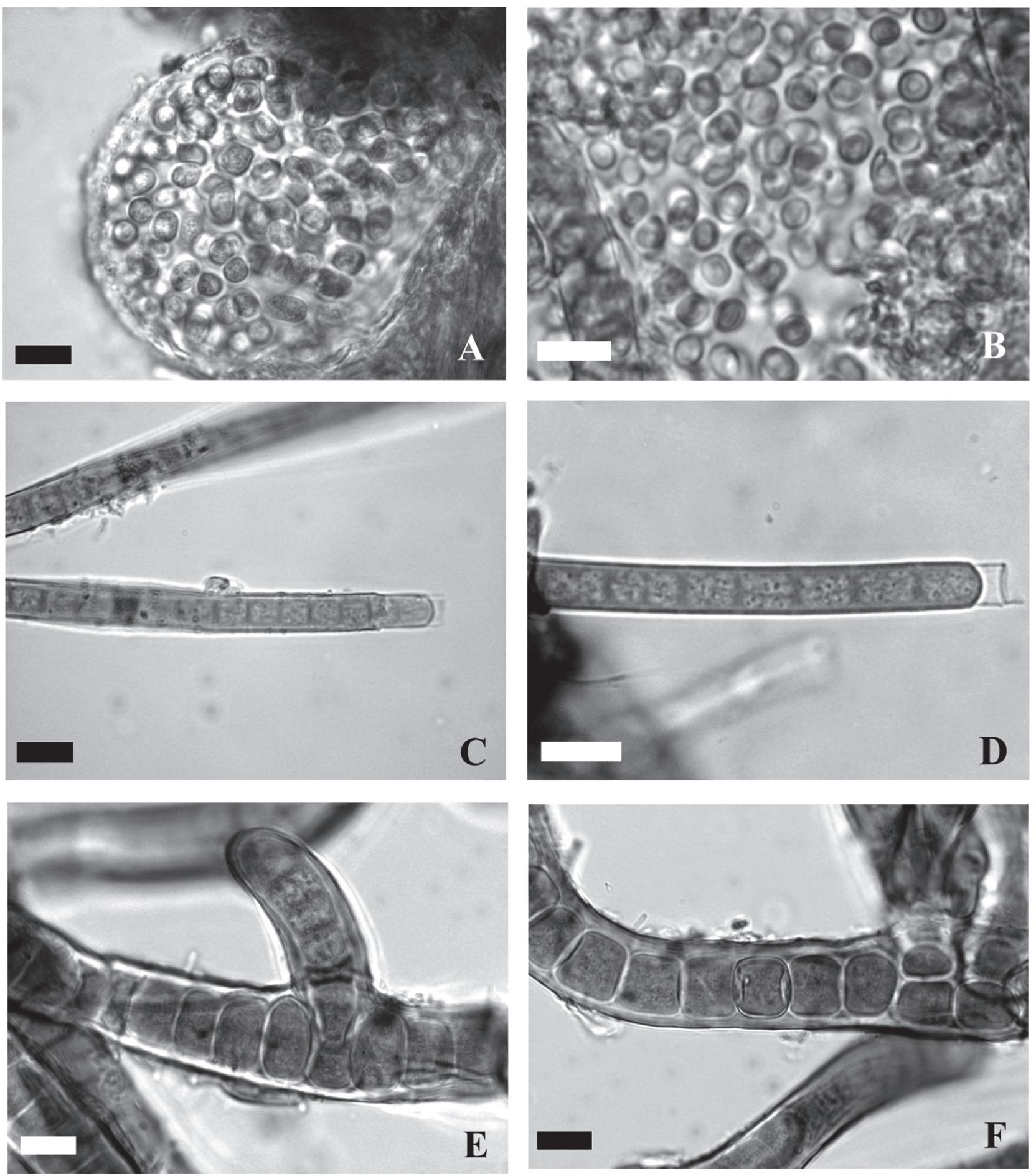

Figure 2. A-B. Aphanothece vaginata. C-D. Phormidium arboricola. E-F. Hapalosiphon santannae. Scale bars $=10 \mu \mathrm{m}$.

The taxonomic knowledge of aerophytic cyanobacterial communities is proved to be insufficient to offer a solid background on biodiversity patterns, especially in tropical regions. Ideally, molecular approaches are recommended to better characterize the species but aerophytic cyanobacteria are difficult organisms to cultivate and, consequently, the characterization of the populations from nature is still an important step in the recognition of the specific tropical flora and for understanding cyanobacterial diversity in different ecosystems and regions (Komárek \& Komárková-Legnerová 2007; Sant'Anna et al. 2007). It is hoped that studies dealing with aerophytic cyanobacterial communities are encouraged to provide a good basis for group taxonomy, phylogeny and diversity. 
Table 8. Morphometric and ecological characteristics of Hapalosiphon santannae and the closest species.

\begin{tabular}{|c|c|c|c|c|}
\hline & H. aureus ${ }^{1,3}$ & H. fontinalis ${ }^{2}$ & H. stuhlmannii ${ }^{2,3,4}$ & H. santannae \\
\hline Plant mass & & caespitose & caespitose & Filaments tangle, caespitose \\
\hline Filament diam. & $11.5-12.5 \mu \mathrm{m}$ & $12.0-24.0 \mu \mathrm{m}$ & $10.0 \mu \mathrm{m}$ & $16.0-20.0 \mu \mathrm{m}$ \\
\hline Lateral branches & long and narrow & narrower than main filament & & short/long \\
\hline Sheath & wide & $\begin{array}{l}\text { colorless or yellowish } \\
\text { in the oldest portions }\end{array}$ & fine and colorless & yellow \\
\hline Cell length $(\mu \mathrm{m})$ & $4.0-8.0$ & & & $8.0-12.0$ \\
\hline $\mathrm{L} / \mathrm{D}$ & & longer than wide & quadratic or shorter & $0.6-0.8$ times longer than wide \\
\hline Heterocytes & $\begin{array}{l}\text { intercalar, } \\
\text { subcilindrical, } \\
\text { subquadratic }\end{array}$ & & spherical or bluntly & intercalar and lateral \\
\hline Ecology & $\begin{array}{l}\text { swamps, wet soil - } \\
\text { tropical region, Brazil }\end{array}$ & lentic environment - cosmopolitan & $\begin{array}{c}\text { lentic environment - Africa; } \\
\text { edaphic, wet walls, aquatic } \\
\text { subtropical and tropical } \\
\text { regions, Brazil }\end{array}$ & aerophytic - tropical region, Brazil \\
\hline
\end{tabular}

${ }^{1}$ Frémy (1924), ${ }^{2}$ Frémy (1930), ${ }^{3}$ Silva \& Sant'Anna (1990), ${ }^{4}$ Azevedo et al. (1996).

\section{Acknowledgements}

Authors are indebted to Fapesp (2007/01667-8) for fellowship to NMLS and financial support through the project "Fauna e flora de fragmentos florestais remanescentes no noroeste paulista: base para estudos de conservação da biodiversidade" (2004/04820-3); to CNPq grants to LHZB (307243/2006-0) and to ONJ (305153/2006-4). We are also grateful to Jeferson Luizi Pereira, Marcos Vinícius Bernardino and Vinícius Agostini Machado, for help during field work and Dr. Luís Augusto Schmidt Totti (IBILCE/UNESP) for the Latin diagnoses.

\section{References}

Allen, M.B. 1956. Photosynthetic nitrogen fixation by blue-green algae. The Scientific Monthly 83: 100-106.

Azevedo, M.T.P. 1991.Edaphic blue-green algae from the São Paulo Botanical Garden, Brazil. Algological Studies 64: 503-526.

Azevedo, M.T.P.; Nogueira, N.M.C. \& Sant'Anna, C.L. 1996. Criptógamos do Parque Estadual das Fontes do Ipiranga, São Paulo, SP. Algas, 8: Cyanophyceae. Hoehnea 23: 1-38.

Branco, L.H.Z.; Azevedo, M.P.T.; Sant'Anna, C.L. \& Komárek, J. 2006a. New morphospecies of Symplocastrum (Phormidiaceae, Oscillatoriales) from aerophytic habitats in Brazil. Algological Studies 121: 23-33.

Branco, L.H.Z.; Komárek, J.; Azevedo, M.T.P.; Sant'Anna, C.L. \& Watanabe, M. 2006b. The cyanobacterial genus Cyanoarbor Wang (Chroococcales, Entophysalidaceae) and its occurrence in Brazil. Nova Hedwigia 82: 365-380.

Büdel, B.; Weber, H.M.; Porembski, S. \& Barthlott, W. 2002. Cyanobacteria of inselbergs in the Atlantic rainforest zone of eastern Brazil. Phycologia 41: 498-506.

De, P.K. 1939. The role of blue-green algae in nitrogen fixation in rice fields. Proceedings of the Royal Society of London 127: 121-139.

Evans, R.D. \& Johansen, J.R. 1999. Microbiotic crusts and ecosystem processes. Critical Reviews and Plants Sciences 18: 183-225.

Flechtner, V.R.; Jeffrey, J.R. \& Clark, W.H. 1998. Algal composition of the microbiotic crusts from the Central Desert of Baja California, Mexico. The Great Basin Naturalist 54: 295-311.

Fletcher, J.E. \& Martin, W.P. 1948. Some effects of algae and molds in the rain-crust of desert soils. Ecology 29: 95-100.

Frémy, P. 1924. Contribuition à la flore algologique de l'A frique équatoriale française. Revue Algologique 1: 1-23.

Frémy, P. 1930. Les Mixophycées de I'Afrique équatoriale française. Archives Botaniqque Mémoires 3: 1-508.

Hoffmann, L. 1989. Algae of terrestrial habitats. The Botanical Review 55: 77-105.

Hoffmann, L; Komárek, J. \& Kaštovský, J. 2005. System of cyanoprokaryotes (cyanobacteria) - state in 2004. Algological Studies 117: 95-115.
Johansen, J.R. 1993. Cryptogamic crusts semiarid and arid lands of North America. Journal of Phycology 29: 140-147.

Komárek, J. \& Anagnostidis, K. 1998. Cyanoprokaryota - 1. Teil: Chroococcales. Pp. 1-548. In: Ettl, H.; Gärtner, G.; Heynig, H. \& Mollenhauer D. (eds.). Süsswasserflora von Mitteleuropa 19/1. Heidelberg, Gustav Fischer.

Komárek, J. \& Anagnostidis, K. 2005. Cyanoprokaryota - 2. Teil: Oscillatoriales. Pp. 1-759. In: Büdel, B.; Gärtner, G.; Krienitz, L. \& Schagerl, M. (eds.). Süsswasserflora von Mitteleuropa 19/2. Heidelberg, ElsevierSpektrum.

Komárek, J. \& Komárková-Legnerová, J. 2007. Several rare freshwater planktic Cyanobacteria (Cyanoprokaryotes) from reservoirs in South America. Hoehnea 34: 49-58.

Lemes-da-Silva, N.M.; Branco, L.H.Z. \& Necchi-Júnior, O. 2010. Corticolous Green algae from tropical forests remnants in the northwest region of São Paulo, Brazil. Revista Brasileira de Botânica 33: 215-226.

Oliveira, B.A.D. 1976. Contribuição ao estudo taxonômico das cianofíceas heterocistadas continentais do Estado do Rio de Janeiro, Brasil. 140 p. Tese (Livre-Docência) - Universidade Federal do Rio de Janeiro.

Oliveira, M.S.B.; Oliveira, N.A.; Dainesi, M.B. \& Cardoso, E.J.B.N. 1980. Ocorrência de algas cianofíceas em dois solos do município de Piracicaba. O Solo 72: 62-64.

Rindi, F. \& Guiry, M.D. 2004. Composition and spatial variability of terrestrial algal assemblages occurring at the bases of urban walls in Europe. Phycologia 43: 225-235.

Sant'Anna, C.L. 1984. Flora de Cyanophyceae associada a briófitas, município de Campina Verde, MG. Rickia 11: 129-142.

Sant'Anna, C.L.; Branco, L.H.Z. \& Silva, S.M.F. 1991a. A new species of Gloethece (Cyanophyceae, Microcystaceae) from São Paulo State, Brazil. Algological Studies 62: 1-5.

Sant'Anna, C.L.; Silva, S.M.F. \& Branco, L.H.Z. 1991b. Cyanophyceae da Gruta-que-chora, município de Ubatuba, Estado de São Paulo, Brasil. Hoehnea 18: 75-97.

Sant'Anna, C.L.; Azevedo, M.T.P.; Branco, L.H.Z. \& Komárek, J. 2007. New aerophytic morphospecies of Nostoc (Cyanobacteria) from São Paulo State, Brazil. Hoehnea 34: 95-101.

Silva, S.M.F. \& Sant'Anna, C.L. 1990. Stigonemataceae (Cyanophyceae) do estado de São Paulo, Brasil, 1: O gênero Hapalosiphon Naegeli ex Bornet \& Flahaut. Hoenea 17: 63-91.

Singh, R.N. 1961. Role of blue-green algae in nitrogen economy of India. New Delhi, Indian Council of Agricultural Research.

Tirkey, J. \& Adhikary, P. 2006. Blue green algae in the biological soil crusts of different regions of India. Weinheim 117: 280-306.

Whitton, B.A. 2000. Soils and rice fields. Pp 233-255. In: Whitton, B.A. \& Potts M. (eds.) The Ecology of Cyanobacteria. Dordrecht, Kluwer Academic.

Versão eletrônica do artigo em www.scielo.br/abb e http://www.botanica.org.br/acta/ojs 